Tarih Kültür ve Sanat Araştırmaları Dergisi

Revue des Recherches en Histoire Culture et Art

مجلة البحوث التاريخية و الثقافية والفنية
Vol. 6, No. 6, December 2017

Copyright (C) Karabuk University

http://kutaksam.karabuk.edu.tr

\title{
DOI: 10.7596/taksad.v6i6.1338
}

Citation: Sitdikova, F. B., Eremeyeva, G. R., \& Valieva, G. F. (2017). Implicit Negation in Dialogue Discourse. Journal of History Culture and Art Research, 6(6), 175-181. doi:http://dx.doi.org/10.7596/taksad.v6i6.1338

\section{Implicit Negation in Dialogue Discourse}

\author{
Farida Bizyanovna Sitdikova1, Guzel Rinatovna Eremeyeva², \\ Gulnara Firdusovna Valieva ${ }^{3}$
}

\begin{abstract}
Our paper presents a research in cognitive linguistics and considers implicit negation dialogue utterances. Implicitness exists in all natural languages and can be considered as one of the most important features in the verbal communication process. It is well known that utterances in dialogues have a high degree of the implicitness which is due to the fact that the communicants share the situation, the context and the background knowledge. The paper considers some common ways of expressing implicit negation in the dialogue utterances. The main results of the study consist in the description of the mechanism for recognizing the implicit meaning and identifying typical cases of implicit negation in dialogue utterances characterized by the asymmetry of interrogative and response replicas. The materials of the paper can contribute into the language and thinking correlation problem and be of some interest for linguists, psycho-linguists, experts in logics and philosophy.
\end{abstract}

Keywords: Implicitness, Implicit negation, Implicit meanings, Implicature, Dialogue, Intonational phraseological units.

\footnotetext{
${ }^{1}$ Ph.D., Senior lecturer, Kazan Federal University Address: Kazan, Kazan Federal University, Kremliovskaya str, 18, 420008, Kazan, Russian Federation. E-mail: farida7777@yandex.ru

2 Ph.D., Associate professor, Kazan Federal University Address: Kazan, Kazan Federal University, Kremliovskaya str, 18, 420008, Kazan, Russian Federation.

${ }^{3}$ Senior lecturer The Institute of Foreign Relations, History and Oriental Studies, Kazan Federal University Address: Kazan, Kazan Federal University, Kremliovskaya str, 18, 420008, Kazan, Russian Federation.
} 


\section{Introduction}

Negation is a category related to the interaction of language and thinking, therefore it is studied by such sciences as logic, philosophy, psychology, and also linguistics. Most researchers of negation (O. Espersen, T. Givon, L.R. Horn, V. Heinemann, etc.) consider negation as a mental conceptual category that finds expression in the language (Polovinina, 2006).

Our paper considers implicit negation and the ways of expressing it in the dialogue discourse. Negation can be expressed both in explicit and implicit ways, and it can be found at all language levels, since the negation category can use a wide range of means for expressing itself (lexical, morphological, syntactical, semantic and prosodic ones).

Many researchers while studying the negation category noted that the semantic of negative sentences often does not correspond to their structure. A sentence can be affirmative or question in form, but semantically might contain implicit negation. In other words, implicit negation is manifested in the nonexpressed meaning of formal grammatical indicators.

Let us illustrate this statement with an example (due to the difference in fonts we are giving the transliteration of Tatar text).

- Militziage haber ittegezme?

-Monda telefonni ezgenner (Galiullin, 1997: 55).

- Have you phoned to the police station?

- The telephone line has been cut off.

In this example, the response replica of the dialogue contains a negative answer to the question asked. To call the police, you need a phone. The telephone wire was cut off. Consequently, the police were not informed (the conclusion is omitted).

In this case we can talk about the implicit way of expressing negation. Some sentences in our speech can be omitted because they refer to common knowledge, but communicants can understand them easily.

\section{Methods}

Let us introduce the terms implicit meaning and implicature. In all languages the utterance meaning is formed both from explicitly expressed components and also unexpressed, but implied ones. By implicit meaning in general we understand different kinds of implicit information (that is, presupposition, contextual meaning, implicature, subtext) which have been interpreted by different authors in different way

According to modern approach, the meaning of an utterance is formed both from explicitly expressed components and also unexpressed, but implied ones. By implicit meaning of an utterance we understand the meaning that is created from the interaction of language units with the cognitive sphere of the utterance recipient. The utterance itself can be considered as a stimulus that draws knowledge from the cognitive sphere to form the meaning (Kashichkin, 2003).

According to modern approach, the implicit meaning of an utterance is a complicated multi-level structure that includes presuppositions, specific contextual meaning and implicature. Implicature is the implicit meaning which can be drawn from the utterance as a result of implication using the elements of the cognitive sphere (background knowledge). In the example above the implicature represents the logical conclusion that was not expressed verbally. 
The implicit way of expressing negation is more difficult to perceive, since it does not have stable formal grammatical features. While an explicit negation is always available for understanding, for perceiving implicit negation the intonation, the context, the order of words (linguistic factors), and also the speech situation, status, age, gender, cultural level (extralinguistic factors) play a special role. An important role is played also by the pragmatic orientation that the author attaches to the utterance, wishing to express an attitude toward certain phenomena of reality.

In this paper we have made an attempt to consider and describe some types of implicit negation which are common for dialogues. We have made use of component analyses and description methods. As language examples we have used extracts from Tatar fiction containing implicit negation.

\section{Results}

In this article, we have tried try to consider some ways of expressing the implicit negation encountered in the dialogue.

Dialogue is considered a special kind of text, because in it "the necessary content consists of a meaning contained in speech segments with an explicit verbal expression, and also from the implied meaning. The general meaning of utterances is formed with the support of the general experience of the speakers ..., the elements of the conversation, taking into account the gestures and facial expressions, as well as the orientation to the language context. This allows many things not to be expressed verbally because of its sufficient clarity for the speakers" (Devkin, 1981: 6). The degree of implicitness of sentences of dialogical spoken language is especially great in the case when participants in a speech act are united by the same situation and perceptive-associative base, much can be said "between the lines".

Practice shows that in the dialogues there is an asymmetry of interrogative and response replicas, indicating the presence of a hidden meaning, and quite often the response replica contains a negation. Moreover, negative semantics can be accompanied by a variety of additional shades of meaning (mockery, irony, surprise, doubt, categorical disagreement, etc.).

As mentioned above, implicit negation can exist at all levels of the language, beginning with the word. Considering the implicit denial, we limited ourselves only to the level of the utterance of the dialogue. The simplest case of dialogue is the question-answer structure, while the communicants leave much "between the lines", which is a manifestation of implicitness.

Language examples for the article are collected from Tatar fiction literature, although you can speak about implicit negation in any natural language. Considering the examples, we have identified the following cases, when the response replicas of the dialogue contain implicit negation.

1. The general case. The dialogue replica contains a statement that implicitly contains the negation of the fact from the previous replica. Using the implication mechanism, context and situation, a specific contextual meaning and implicature of the replica can be extracted. E.M. Lulcheva notes that "despite the fact that negation, expressed indirectly / implicitly / indirectly, is more difficult to detect, its use is justified in those cases when it is necessary to make a hint or express an ironic attitude to something" (Lulcheva, 2013). Consider the following example:

- $\quad$ Ul minga sezne senglem didde.

- $\quad$ Aning seglese ya tumagan, ya aida... (Gimatdinova, 2002: 317).

- $\quad$ He told me you are his sister.

- $\quad$ His sister either hasn't been born or is on the Moon... 
The highlighted expression indicates a sarcastic irony that one can deduce a logical implicature that the above-mentioned sister does not exist.

2. Use of fixed phrases. If in the first case the statement was arbitrary, but the second case is when the negative answer is contained in fixed, specially intonationally worded phrases, which modern researchers call intonational phraseological units (IFU). Examples of negative IF in the Tatar language: Alle taggi (What are you taking about?), Kelderma (Don't make me laugh), Bashimi catirma (Don't fool me), etc. Such IFU are especially common for conversational dialogical speech. An example of a statement containing IFU:

- Min hooligan malaiga oshaganmi, apa?

- $\quad$ Alle tagi, enem. Yezeng-biteng matur, kienyeng firt ta yze (Gimatdinova, 2002: 319).

- Auntie, do I look like a hooligan?

- What are you talking about, sonnie? You look great, and your clothes seem to be expensive.

3. The reply to a question is formally an interrogative sentence, but implicitly contains negation or objection (This case partly overlaps with the second, because IFU can also take the form of a question).

Such a variety of questions were investigated by many researchers of Russian colloquial speech (G.V. Gavrilova, V.Yu. Melikyan, D.N. Shmelyov, N.D. Arutyunova, etc.), who noted the existence of response replicas in the form of questions that they are an expression of the emotional reaction of the speaker and implicitly contain the meaning of the negation of the previous statement, disagreement, objection, indignation, protest, etc. For example, GF Gavrilova writes about interrogative sentences that are characterized by "asymmetry of form and content, where the questionnaire form is just a "mask" of content that does not correspond to it" (Gavrilova, 1999: 91).

N.D. Arutyunova notes that "in the Russian language the process of transforming special questions into general modal reactions with the meaning of confirmation, consent, objection, refusal, etc. proceeds quite actively and covers almost all types of private issues" (1998: 674). N.A. Nekrasova argues that such interrogative sentences, complicated by additional connotations of objection, disagreement, indignation, etc., allow saving language resources (2003: 64). Apparently, this phenomenon is peculiar not only to the Russian language, since in the Tatar language it is also possible to single out conventionally fixed replicas of this type in the language.

For example, response replies-questions starting with Kem (Who), Nindi (What kind of), Kayan, Kaya (Where, Where... from) implicitly deny the previous statement, disagreement with it:

- Sin nik ggel kul uynatasin, Bakir?

- Kem aita uynata dip?(Gimatdinova, 2003: 99).

- Why don't you keep your hands to yourself, Bakir?

- Who says this?

It should be noted that often such interrogative replicas (for example, Kayan belim?, How do I know?) are fixed in the language as typed, stable phrases and become IFU.

4. Consider the most interesting case, when a statement is formally an affirmative answer to a question, but the corresponding intonation and the context show that it contains negation. In dialogical speech intonation and logical stress play a huge role, helping to identify the presence of negation in statements. Intonation is capable of giving negative structures to non-negative structures. Logical stress, interacting with other factors, contributes to a precise understanding of the implicit structure of the utterance. 
In the following example the implicit meaning of the highlighted phrase is absolutely the opposite of its literal meaning:

- Tenlya Bakir kapkagisga tashlar tomirdi. Chinmi, almam?

- Chin, apa, - dide Vasilya yelmaep. - Kuzenge chalinmadimeni, kapka yantaigan, koima ishelgan,

taraze vatilgan... (Gimatdinova, 2003: 104).

- $\quad$ Is it true that Bakir threw stones to your gate last night?

- Yes, it's true, auntie, - Vasilya smiled. - Haven't you noticed that the gate squinted, the fence is piled, the windows are all broken...

In this case, the context (smiled) and the corresponding intonation help to extract the correct implicature of the last utterance. The girl denies the gossip told by her relative, but makes it in a humorous form.

5. One of the ways to express negation implicitly is conditional statements that carry the meaning of the impossibility of the action at the moment or the absence of something. For example:

- $\quad$ Alam da ber bala tabam ale min, - didem.

- $\quad$ Sin buiga uzsang, min un kulimi kisteram, vallahi! Ha-ha-ha! (Gimatdinova, 2002: 48).

- $\quad$ So what if I give birth to a child? -I said.

- If you become pregnant, I will let cut off my right hand, by God! Ha-ha-ha!

From the last utterance, one can draw an implicature about the impossibility of the event specified in the first statement.

In dialogues we can also see a combination of the above-mentioned cases within one replica.

\section{Discussion}

The first person who thoroughly examined the category of negation was probably O. Espersen (1917) who wrote a book devoted to negation. Nowadays there are also a lot of papers by domestic researchers considering implicit ways of expressing negation in the English language: E.M. Lulcheva (2013), V.N. Pilatova (2002), M.S. Malsagova (2017) etc.

Implicit negation in the Russian language was studied by E.V. Paducheva (2011), T.A. Shutova (1996), E.G. Kazimyanetz (1987), etc.

But our paper is the first research in Tatar Linguistics in this field.

\section{Summary}

Negation is a mental conceptual category that finds expression in the language. It can be expressed both explicitly and implicitly at all language levels due to the inherent capability of natural languages to use a wide set of means of expressing negation (lexical, morphological and syntactic, semantic and prosodic). Our research focuses on the ways of expressing some common ways of implicit negations in dialogues using examples from Tatar fiction literature.

\section{Conclusions}

Verbal communication is impossible without implicitness, which plays an important role in creating and understanding speech utterances. The implicit meaning is formed from the interaction of the verbally 
expressed content of the utterance and parts of the cognitive environment of the communicants according to the principle: stimulus - context - interpretation. The utterance itself can be considered as a stimulus drawing background knowledge of communicants which enable them to extract the implicit meaning of the utterance.

Intonation, the context as a whole, the order of words, as well as extralinguistic factors (speech situation, status, age, gender, cultural level and extra-linguistic experience of communicants) acquire a special role in order to understand the negative meaning of the statement with implicit negation (in other words, for drawing the implicature from the utterance).

The implicitness degree of utterances of dialogical colloquial speech is especially high because participants in the speech act are united by the same situation and perceptive-associative base, much can be said "between the lines". Accordingly, cases of implicit negation are most often found in the dialogue.

The most common cases of implicit negation in the dialogue utterances illustrated by language examples have been described and analyzed. The article makes contribution into Tatar linguistics and also the interaction of language and thinking problem.

\section{ACKNOWLEDGEMENTS}

The work is performed according to the Russian Government Program of Competitive Growth of Kazan Federal University.

\section{References}

Arutyunova, N. D. (1998). Yazik i mir cheloveka. Moscow: Языки русской культуры.

Devkin, V. D. (1981). Dialog: Nemetzkaya razgovornaya rech' v sopostavlenii s russkoy. Moscow: Vishaya shkola.

Espersen, O. (1917). Negation in English and Other Languages. Copenhagen: Høst.

Galiullin, T. N. (1997). Taube. Kazan: Taтarstan kitap nashriyate.

Gavrilova, G. F. (1999). Voprositelniye konstruktzii $v$ ih funktzionalno-semioticheskom aspecte // Yasikovie yedinitzi: Logika I semantika, funktzii I pragmatika. Taganrog.

Gimatdinova, N. (2002). Ikebezge de avir. Kazan.

Gimatdinova, N. (2003). Parly yalgiz. Kazan.

Kashichkin, A. V. (2003). Implitzitnost v kontexte perevoda. Dissertation kand. filol. nauk. Moscow.

Kazimyanetz, E. G. (1987). Sposobi virazheniya otritzaniya v sovremennom russkom yazike: bilingvalniy analiz. Dissertation. Candidate of Philological Sciences. Moscow.

Lulcheva, E. M. (2013). Implitzitniye sposobi virazheniya otritzaniya. Vestnik IGLU. URL:

Malgsagova, M. S. (2017). Implitzitnoye otritzaniye vo frazeologizmah angliyskogo yazika. 
Nekrasova, N. A. (2003). Implitzitnost' paznourovnevih sintaksicheskih construktziy $v$ russkom i angliyskom yazikah. Dissertation. Candidate of Philological Sciences. Rostov-na-Donu.

Paducheva, E. V. (2011). Implitzinoye otritzaniye i mestoimeniya s otritzatel'noy polyarizatziei. Voprosi yazikoznaniya, 1, 3-18.

Pilatova, V. N. (2002). Expressivnoye otritzaniye v sovremennom angliyskom yazike. Dissertation. Candidate of Philological Sciences. St. Petersburg.

Polovinina, S. G. (2006). Implicitnie markeri otritzaniya v nemetzkoyazichnom reklamnom diskurse. Gumanitarniye issledovaniya, 4.

Shutova, T. A. (1996). Semantika otritzaniya I sposobi eyo implitzitnogo virazheniya v russkom yazike. Dissertation. Candidate of Philological Sciences. St.Petersburg. 